\title{
堤体端部の影響に着目した捨石潜堤の 変形について \\ INFLUENCE OF SUBMERGED BREAKWATER HEAD ON DEFORMATION OF SUBMERGED BREAKWATER BODY
}

\author{
荒木進歩 1 宮崎敏弘 2 ・柳原哲也 ${ }^{3} \cdot$ 新島 $\quad$ 宏 $^{3} \cdot$ 出口一郎 4 \\ Susumu ARAKI, Toshihiro MIYAZAKI, Tetsuya YANAGIHARA, Hiroshi NIIJIMA \\ and Ichiro DEGUCHI \\ 1正会員 博 (工) 大阪大学大学院助手 工学研究科土木工学専攻 (テ565-0871 大阪府吹田市山田丘2-1) \\ 3学生員 大阪大学大学院 工学研究科土木工学専攻 (テ565-0871 大阪府吹田市山田丘2-1) \\ 4正会員 工博 大阪大学大学院教授 工学研究科土木工学専攻 († 565-0871 大阪府吹田市山田丘2-1)
}

2 修(工) 五洋建設株式会社

\begin{abstract}
Deformation of submerged breakwater was examined by three-dimensional experiments to investigate the influence of the deformation of the head of submerged breakwater on the total damage of the breakwater. The eroded area at the breakwater heads was larger than that at the breakwater trunk. The rubble stones moved from the upstream head of longshore current were accreted within one wave length from the end of the upstream head. Therefore, there are two types of accretion at the leeside of the submerged breakawter depending on the ratio of the breakwater length to wave length. The difference in deformation between two-dimensional and three-dimensional experiments is large, especially at the upstream head of the breakwater.
\end{abstract}

Key Words : deformation, submerged breakwater, breakwater head, three-dimensional experiment

\section{1.はじめに}

海岸構造物は，設計值を上回る外力が作用した場 合において，変形が生じても粘り強く機能を発揮す る海岸構造物であることが望ましい，しかし，現行 の設計法では，設計外力に対する安定性の照査を行 うのみであり，それ以上の外力に対する構造物の挙 動（変形および変形に伴う水理機能変化）は検討さ れていない。設計外力以上の波浪が来襲する可能性 がある以上, その際の構造物の挙動を明らかにして おくことは防災上，重要であると考えられる。した がって, 構造物の終局状態を考え, 変形・崩壊過程 およびそれに伴う水理機能の変化を明らかにするこ とが必要となる。

本研究では，変形や被災に関する報告が十分にな されていない捨石潜堤を対象とし，堤体の崩壊過程 の解明および変形に伴う水理機能変化の解明を行う ことを目的とする。潜堤の堤体には巨石や被覆ブ ロック等が用いられており, 設計外力に対して堤体 の構成材料が飛散しないように十分な重量を確保し て表層を被覆している。しかし, 被災事例（例えば

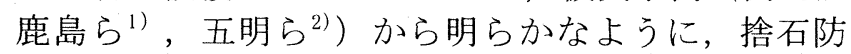

波堤や消波ブロック被覆堤の端部（堤頭部）は被覆 材が飛散しやすく，被災を受けやすい。このことか ら，捨石防波堤および消波ブロック被覆堤端部の被 覆材の安定性に関する研究（例えば，Burcharth and Frigaard $^{3)}$ ，松見・大野 ${ }^{4)}$ ，木村ら ${ }^{5)}$ ) がなされ， Burcharth and Frigaard ${ }^{3)}$ は端部の被災および斜め入射 波による主幹部の被災の検討が重要であると指摘し

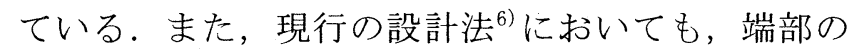
被覆材に対してHudson式等から算出される安定重量 の1.5倍以上の重量を持つ被覆材を用いることが推 奨されている。したがって，没水構造物である潜堤 についても堤体端部は被災を受けやすいと考えられ るが，平面実験により検討された例はほとんどない.

著者ら ${ }^{7)}$ は断面 2 次元実験により捨石潜堤の変形 を検討したが, 変形が早い段階で収束し, 変形後の 天端が静水面よりも上に現れるという結果が得られ た。これは，潜堤の端部は波の作用を受けて変形を 生じやすいが，断面 2 次元実験のために端部の影響 が現れなかったためと考えられる。そこで本研究で は, 捨石潜堤の変形および崩壊には堤体端部の変形 が大きく影響しているのではないかと考え，平面実 験による検討を行う。また，断面 2 次元実験による 
結果と比較し，その相違についても検討する.

\section{2. 水理実験}

水理実験は図- 1 に示す屋外平面水槽を用いて 行った。水槽側壁に設置された造波機から平坦床を 経て, 造波板と $20^{\circ}$ の角度をなして $1 / 10$ の勾配のモ ルタル製固定床が設置されている。この $1 / 10$ 斜面上 に法先水深 $h=19 \mathrm{~cm}$, 天端水深 $4 \mathrm{~cm}$, 天端幅 $B=50 \mathrm{~cm}$, 堤体長 $L r=150 \mathrm{~cm}$ または $200 \mathrm{~cm}$, 法面勾配 $1: 3$ の捨石潜 堤を代表粒径 $D_{50}=0.71 \mathrm{~cm}$ の砕石により作製した。 天 端が静水面よりも上に現れた断面 2 次元実験の結果 は規則波の場合に顕著であったため,ここでは規則 波での実験を中心とした．堤体前面での波高は $H=5$ $\sim 11 \mathrm{~cm}$ ，周期 $T=1.0 \sim 1.5 \mathrm{~s}$ の規則波 2000 波作用させ た. 造波板と固定床斜面の関係から，波の入射角は 堤体に対して $20^{\circ}$ となる.

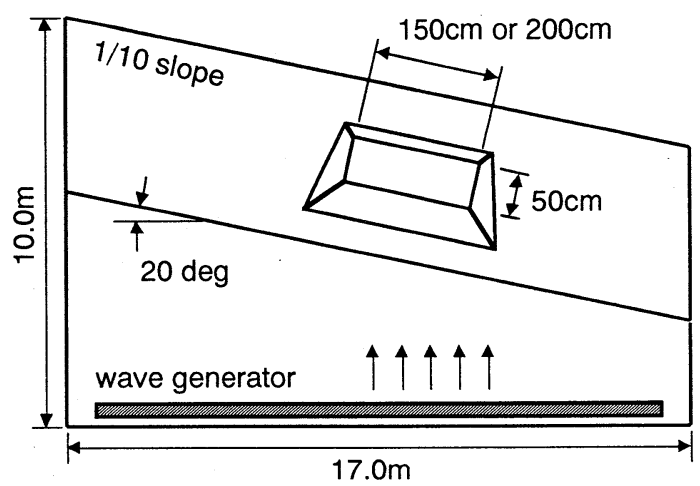

図-1＼cjkstart実験水槽

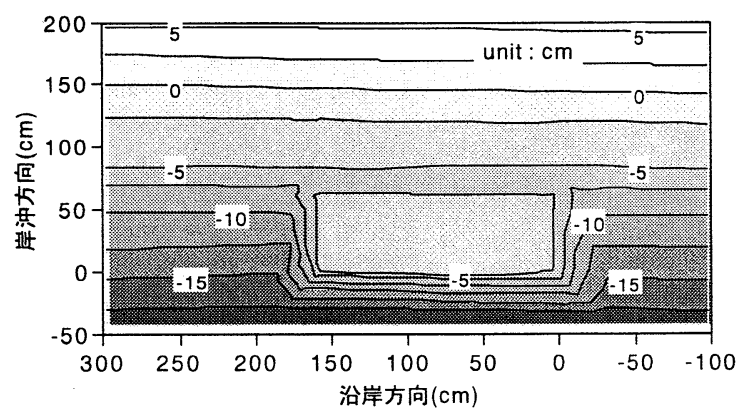

図-2 初期形状 $(L r=150 \mathrm{~cm}$ のケース $)$

堤体の形状は沿岸方向に $10 \mathrm{~cm}$ また $20 \mathrm{~cm}$ 間隔で 設定した測線上で，レーザー变位計により岸沖方向 $に 5 \mathrm{~cm}$ 間隔で測定した。図- 2 に堤体長 $L r=150 \mathrm{~cm}$ の 捨石潜堤の初期形状をコンターで示す。縦軸は岸沖 方向, 横軸は沿岸方向である. 縦軸の原点は沖側の 法肩として岸向きを正, 横軸の原点は沿い流れ上手 側端部として沿い流れ下手側を正とする. 沿い流れ とは，斜め入射であるために潜堤周辺に発生する沿 岸方向の流れ（図面上では左向き）を指し, 以降は 沿い流れの上手側・下手側により潜堤の端部を区別 する。また，容量式波高計により捨石潜堤の沖側お よび背後で水位変動を測定するとともに, 水平 2 成
分の電磁流速計により潜堤背後の水粒子速度を測定 した。なお，潜堤背後の波高計は変形に伴う透過率 の変化を検討するために設置したが，後述するよう に堤体背後での捨石移動が激しく, また捨石の堆積 域でもあるため, 十分な計測ができなかった。

\section{3. 変形形状の平面的特性}

\section{（1）変形形状の全体的な傾向}

図-3 から図-7に，造波終了後に測定された変形 形状の例を法先水深 $h$ で無次元化したコンターで示 す。図- 3 は波高粒径比 $H / D_{50}=8.87$, 相対天端幅 $B / L=0.420$, 相対堤体長 $L r / L=1.26$ のケースでの変形 形状である．Lは潜堤法先での入射波の波長であり， 右上の矢印は波向きを表す。波高粒径比がそれほど 大きくないため堤体変形量は小さいが, 変形が生じ ているのは主として堤体端部である。したがって， 捨石防波堤や消波ブロック被覆堤と同様に，捨石潜 堤においても堤体端部は被災しや寸いことが分かる。 沿い流れ上手側端部では, 沖側斜面から来襲する波 による砕波が天端上に作用するのに加え，堤体側面 から背後に回り込む波が砕波して天端上に作用する ため捨石が移動しやすいと考えられる。一方，沿い 流れ下手側端部においては, 沿い流れ上手側端部と 同等あるいはそれ以上の侵食が生じ，堤体背後のや や側方に堆積が見られる。これは, 砕波等の波の作 用により初期移動を始めた捨石が天端上および堤体 背後の沿い流れにより側方に流出したためと考えら れる.

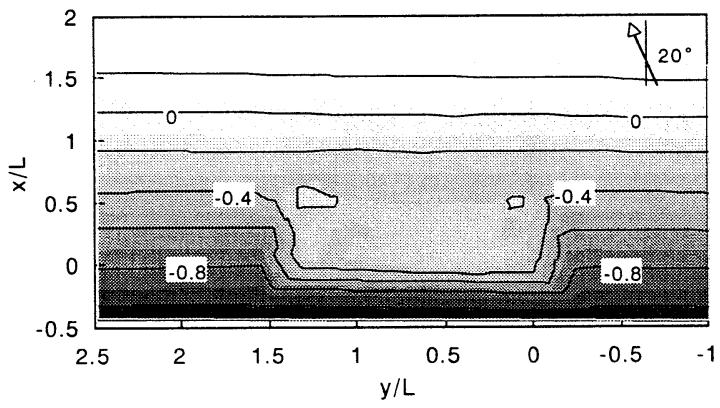

図-3 変形形状 $\left(H / D_{50}=8.87, B / L=0.420, L r / L=1.26\right)$

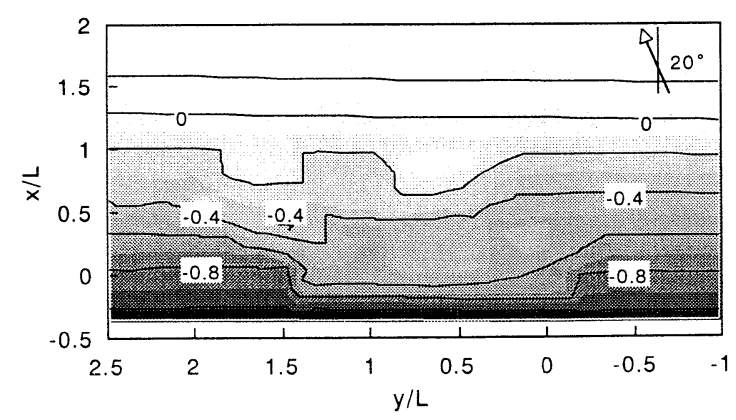

図-4 変形形状 $\left(H / D_{50}=14.9, B / L=0.420, L r / L=1.26\right)$

図- 4 に波高粒径比 $H / D_{50}=14.9$, 相対天端幅 $B / L=0.420$, 相対堤体長 $L r / L=1.26$ のケースでの変形 形状を示す。図ー 3 のケースと相対天端幅および相 
対堤体長は等しいが波高粒径比が大きいため，堤体 の変形量も大きくなっている，沿い流れ上手側端部 では，斜め入射の波の作用により大きく侵食され， 端部の捨石が堤体中央部の背後に堆積した。また沿 い流れ下手側端部でも大きな侵食が生じ，初期移動 を始めた捨石が沿い流れにより側方に流出し，堆積 した.

図- 5 に波高粒径比 $H / D_{50}=14.5$, 相対天端幅 $B / L=0.283$, 相対堤体長 $L r / L=0.849$ のケースでの変形 形状を示す。このケースでは波高粒径比が大きいた め堤体の変形量が大きい。沿い流れ上手側端部の捨 石は岸向きに移動し，初期汀線付近に堆積した。ま た相対堤体長が短いため, 沿い流れ上手側端部の捨 石が堤体背後に移動した後, 一部の捨石が沿い流れ により沿い流れ下手側端部付近にまで移動し，堤体 長全域にわたって背後に捨石が堆積する様子が観察 された。それに対して，図-4に示したケースでは 相対堤体長が長いため, 沿い流れ上手側端部付近に あった捨石の主な堆積位置は堤体中央部の背後であ り，沿い流れ下手側端部付近にまで移動している捨 石は見られなかった。

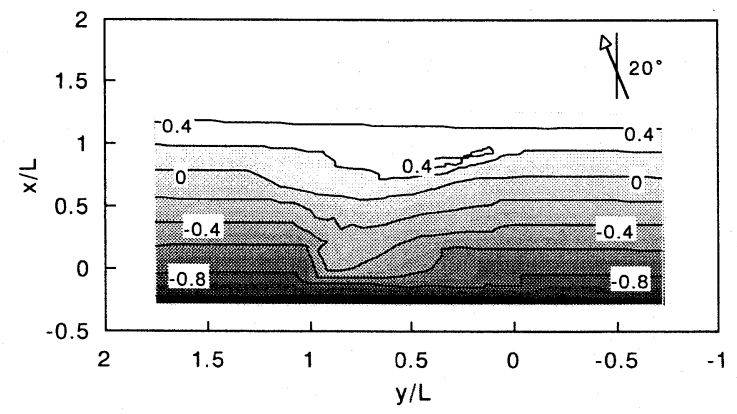

図-5 変形形状 $\left(H / D_{50}=14.5, B / L=0.283, L r / L=0.849\right)$

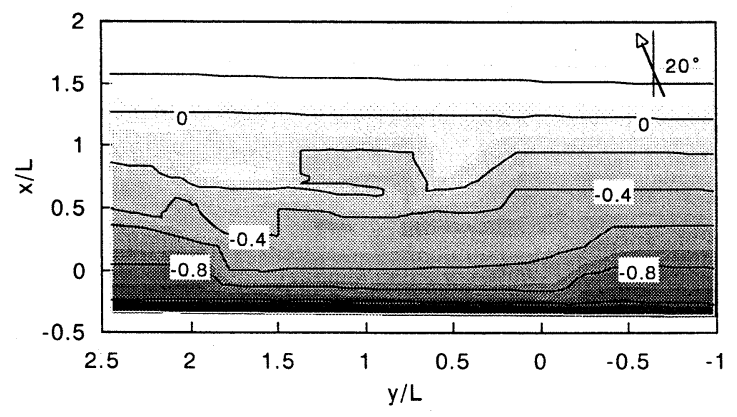

図-6 変形形状 $\left(H / D_{50}=15.8, B / L=0.420, L r / L=1.68\right)$

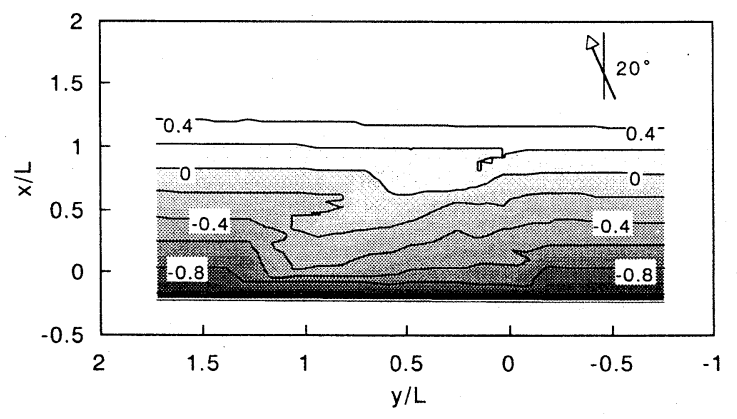

図-7 変形形状 $\left(H / D_{50}=11.1, B / L=0.283, L r / L=1.13\right)$
図- 6 は波高粒径比 $H / D_{50}=15.8$, 相対天端幅 $B / L=0.420$, 相対堤体長 $L r / L=1.68$ のケースでの変形 形状であり, 相対堤体長が長いため, 沿い流れ上手 側端部付近の捨石は堤体中央の背後に堆積した.

図- 7 は波高粒径比 $H / D_{50}=11.1$, 相対天端幅 $B / L=0.283$, 相対堤体長 $L r / L=1.13$ のケースでの変形 形状であり, 相対堤体長がそれほど長くないため, 堤体長ほぼ全域にわたって背後に捨石が堆積した。

\section{（2）岸沖断面諸量の沿岸方向特性}

断面 2 次元実験においては, 断面変形により侵食 された面積は堆積面積と等しい。しかし, 平面実験 においては, 一つの岸沖方向断面に着目すると, 侵 食面積と堆積面積は一般に一致しない。 そこで, 岸 沖断面内での侵食面積と堆積面積の沿岸方向分布を 検討する.

図- 8 に, 図- 3 で示したケース $\left(H / D_{30}=8.87\right.$, $B / L=0.420, L r / L=1.26)$ における岸沖方向断面内での 堆積面積 $A a$ おび侵食面積 $A e$ の沿岸方向分布を示す. 堆積面積 $A a$ および侵食面積 $A e$ は捨石の代表粒径の 2 乗 $D_{50}{ }^{2}$ で無次元化しており, 無次元侵食面積 $A e / D_{50}{ }^{2}$ は被害レベルSに相当する.ただし，ここでは便宜 上, 堆積面積を正, 侵食面積を負の数として扱う. また横軸の沿岸方向距離は, 沿い流れ上手側端部を 原点として堤体長で無次元化している.このケース では堤体変形量が小さいので沿岸方向の捨石移動も 少なく, 岸沖方向断面内で侵食面積と堆積面積はほ ぼ等しくなっている.

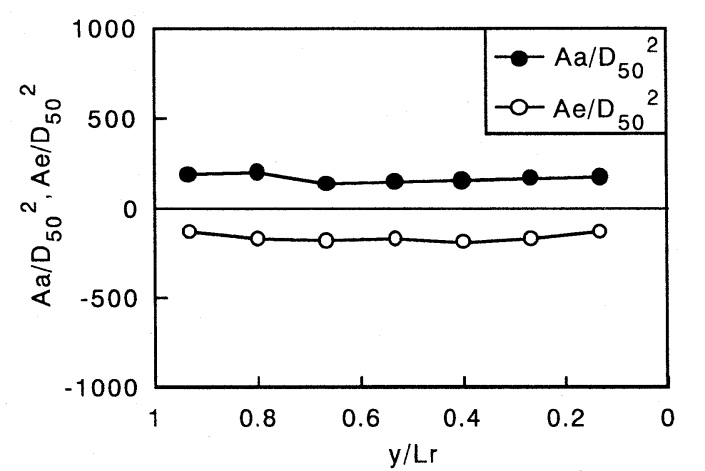

図-8 堆積面積 $A a$ および侵食面積 $A e$ の沿岸方向分布 $\left(H / D_{50}=8.87, B / L=0.420, L r / L=1.26\right)$

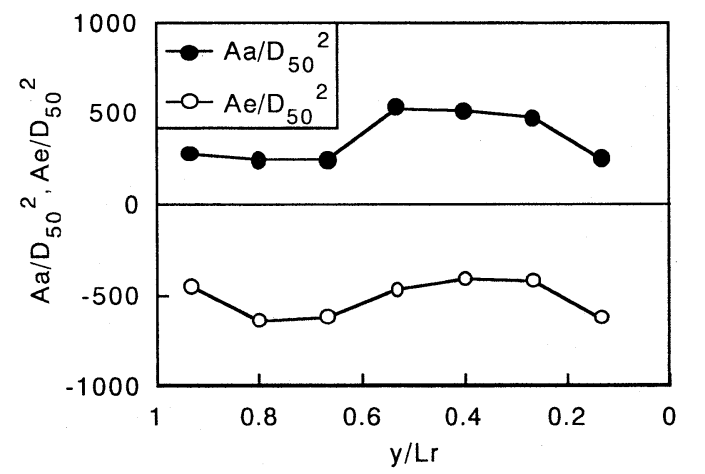

図-9 堆積面積 $A a$ およひ侵食面積 $A e$ の沿岸方向分布 $\left(H / D_{50}=14.9, B / L=0.420, L r / L=1.26\right)$ 


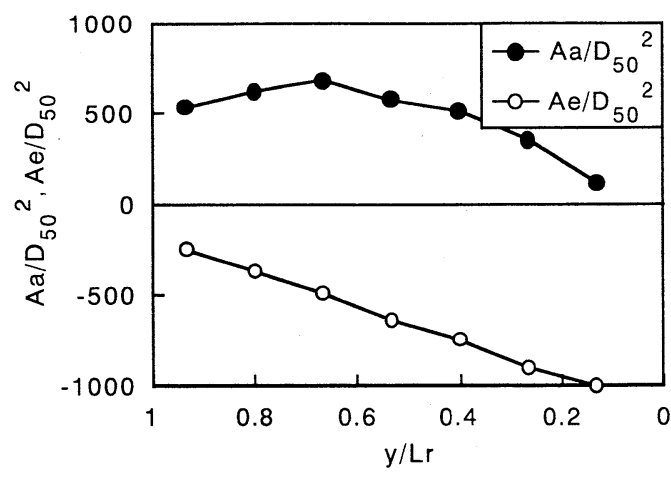

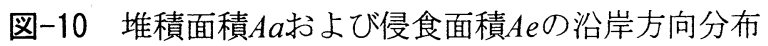
$\left(H / D_{s u}=14.5, B / L=0.283, L r / L=0.879\right)$

図-9に, 図- 4 で示したケース $\left(H / D_{50}=14.9\right.$, $B / L=0.420, L r / L=1.26 ）$ における岸沖方向断面内で

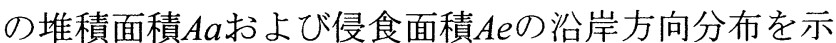
す。図-4で示したように，このケースでは相対堤 体長が長いため，沿い流れ上手側端部の捨石が下手 側端部付近にまで移動することはなく，堤体背後の 堆積域も連続してはいなかった。この図からも, 堆 積面積および侵食面積の両者とも波状の分布をして いることから，沿い流れ上手側が侵食され，堤体中 央部 $(y / L r=0.4 \sim 0.5)$ に捨石が堆積すること，沿い流 れ下手側 $(y / L r=0.7 \sim 0.8)$ では堆積面積が少なく新た に侵食が生じていること，などが分かる。なお，図 面では天端長部分しか示していないが，堤体端部よ りさらに下手側 $(y / L r>1)$ では侵食面積はゼロになる が，堆積面積はゼロにならず分布を続ける。

図-10に, 図一 5 で示したケース $\left(H / D_{50}=14.5\right.$, $B / L=0.283 ， L r / L=0.879 ） に お け る$ 岸沖方向断面内で の堆積面積 $A a$ およ゙侵食面積 $A e$ の沿岸方向分布を示 す. 図-5で示したように，このケースでは相対堤 体長が短いため，沿い流れ上手側の捨石が下手側ま で移動し，堤体背後に連続した捨石の堆積が見られ た。したがって，侵食面積および堆積面積の分布は 図-9のような波状ではなく, 直線状となっている. 沿い流れ上手側から下手側に向けて，侵食面積は一 様に減少し，堆積面積は増加しているので，沿い流 れ上手側から下手側へと捨石が移動している様子が 分かる。沿い流れ上手側端部の無次元侵食面積はほ ぼ-1000である。これは変形前の初期堤体断面積 $A O$ に対して $A o / D_{50}{ }^{2}=-1140$ であることより，沿い流れ上 手側端部付近では，初期状態での捨石がほとんどす べて飛散したことになる。また，堆積面積は図一9 と同様に，沿い流れ下手側端部以降 $(y / L r>1)$ にも分 布している.

図-11に堆積面積の沿岸方向分布を示す。横軸は 潜堤法先での波長 $L て ゙$ 無次元化した沿岸方向距離で あり，沿い流れ上手側端部を原点としている。波高 粒径比にも依存するが，堆積面積は $y / L=0.4 \sim 0.7$ の 範囲でピークを示寸。特に, 変形量が大きいケース において，この傾向は顕著である。このことは, 堆 積面積のピークが沿い流れ上手側端部から 1 波長以

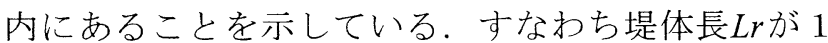

波長より大きい場合は図-4, 図- 6 に示すような堤 体中央部に捨石が堆積する形状となり，堤体長 $L r か ゙$ 1 波長より短い場合は図 -5 , 図- 7 に示すような堤 体長のほぼ全域にわたって背後に捨石が堆積する形 状になることを意味する.

図-12には侵食面積の沿岸方向分布を示す。同様 に，横軸は潜堤法先での波長 $L て ゙$ 無次元化した沿岸 方向距離であり，沿い流れ上手側端部を原点として いる. 沿い流れ上手側端部は大きく侵食されるが, 多くのケースにおいて $y / L=0.4 \sim 0.7$ 付近で侵食面積 は極小となり, その後, 緩やかに増加している。し たがって，堤体長 $\ln$ が 1 波長以上の場合には，沿い 流れ下手側端部での侵食がやや大きくなるこしを示 している。

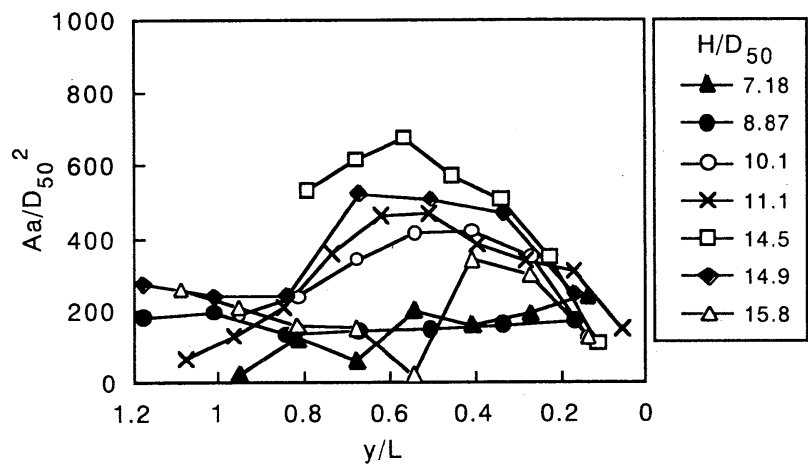

図-11 堆積面積Aaの沿岸方向分布

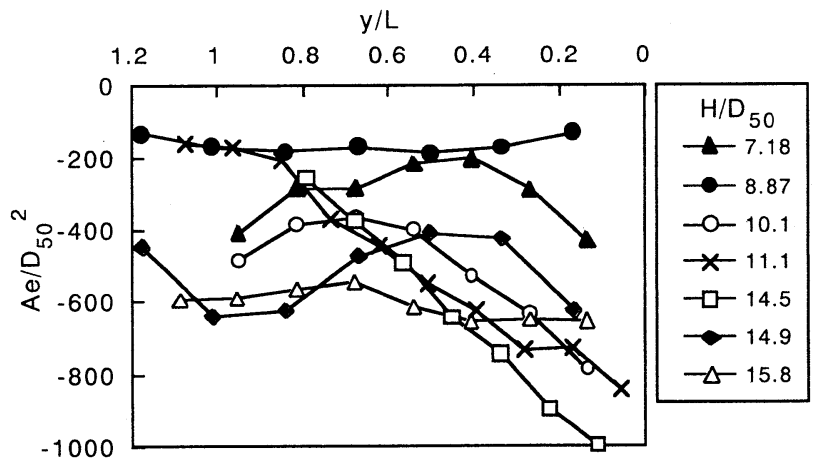

図-12 侵食面積Aeの沿岸方向分布

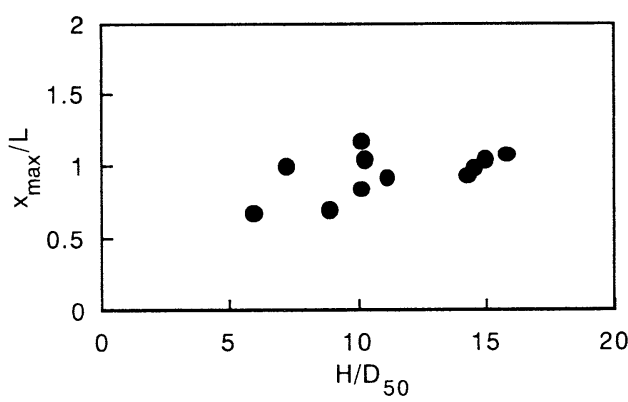

図-13 捨石の岸側堆積位置

\section{（3）捨石の岸向き移動距離}

図-13に，変形が最も岸側にまで及んだ位置，す なわち捨石が最も岸側に堆積した位置 $x_{\text {max }}$ を法先波 長 $L て ゙$ 無次元化して示す．波高粒径比が大きくなる と若干 $x_{\max }$ も大きくなるようであるが，ほとんどの 
ケースにおいて $x_{\max } / L$ が 1 前後の值を示している. 図-3〜図-7からも，初期汀線の位置に関係なく $x / L=$ 1 付近にまで捨石の堆積が生じていることが分かる. また， $x_{\max }$ が生じる沿岸方向の位置は，ばらつきは あるが $y / L<0.4 の$ 範囲にあるケースが多かった。

\section{4. 断面 2 次元実験との比較}

\section{（1）断面形状に関する定性的な比較}

平面実験においては，沿岸方向の流体運動および それに伴う沿岸方向への捨石移動が生じるため，断 面 2 次元実験結果とは異なる結果が得られると考え られる。ここでは，条件がやや異なるが著者ら ${ }^{7)}$ の 断面 2 次元実験の結果を用い, 変形が大きかった図 - 5 のケースの平面実験結果との比較を行う。図一 14(a)〜 (c) に，図-5のケースの岸沖方向の断面形 状を示す。また，比較のために図-15(a)に波高粒径 比 $H / D_{50}=12.1$, 相対天端幅 $B / L=0.168$ のケースの断面 2 次元実験の結果，図 $-15(\mathrm{~b})$ に波高粒径比 $H / D_{50}=29.5$, 相対天端幅 $B / L=0.168$ の断面 2 次元実験 の結果を示す。ただし，断面 2 次元実験はどちらも 1/20勾配の固定床上に作製された捨石潜堤であり， 入射波は1000波までしか作用させていない。
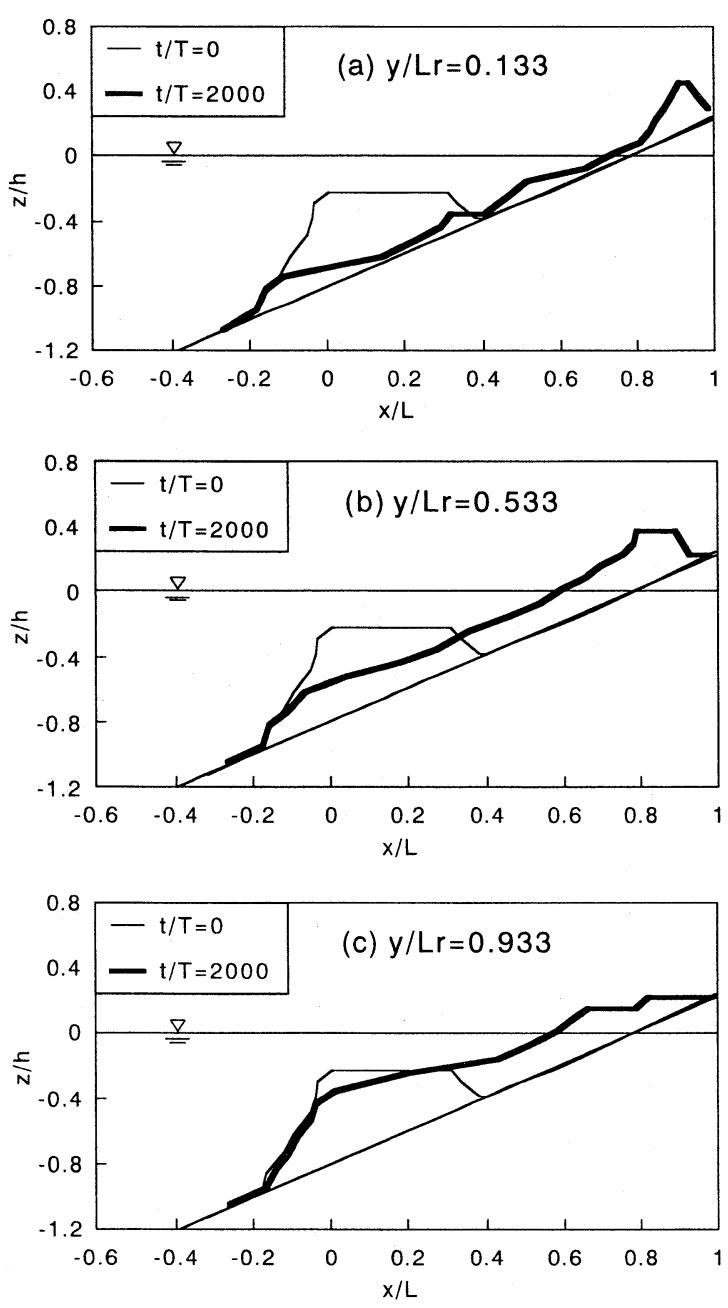

図-14 平面実験による各断面の変形 $\left(H / D_{50}=14.5, B / L=0.283, L r / L=0.849\right)$
条件が異なるため, 平面実験結果と断面 2 次元実 験結果を単純に比較することはできないが，沿い流 れ上手側端部付近 $(y / L r=0.113)$ の断面形状について は, 堤体背後での堆積形状が断面 2 次元実験結果と 似ている。断面 2 次元実験では直角入射であるため, 潜堤は波の作用を受けて変形し，構造物の周囲に発 生する流れの沿岸方向成分は存在しない。したがっ て, 断面 2 次元実験結果との比較から，沿い流れ上 手側端部の変形は主として波の作用によるものであ ると考えられる。しかし，岸向きの捨石移動量には 大きな違いがあり，平面実験では初期汀線付近に捨 石が堆積した。これは，断面 2 次元実験においては 捨石の移動方向の自由度が岸沖方向に限定されてい ること，また潜堤背後で生じた水位上昇が沿岸方向 に消散せず，すべて戻り流れとなって天端上を通過 するためであると考えられる。

一方, 沿い流れ下手側端部付近 $(y / L r=0.933)$ の断 面形状については，断面 2 次元実験結果とは大きく 異なっている。これは沿い流れ下手側端部付近の変 形には，波の作用以外の影響，すなわち沿い流れの 影響が大きいことを示していると言える。
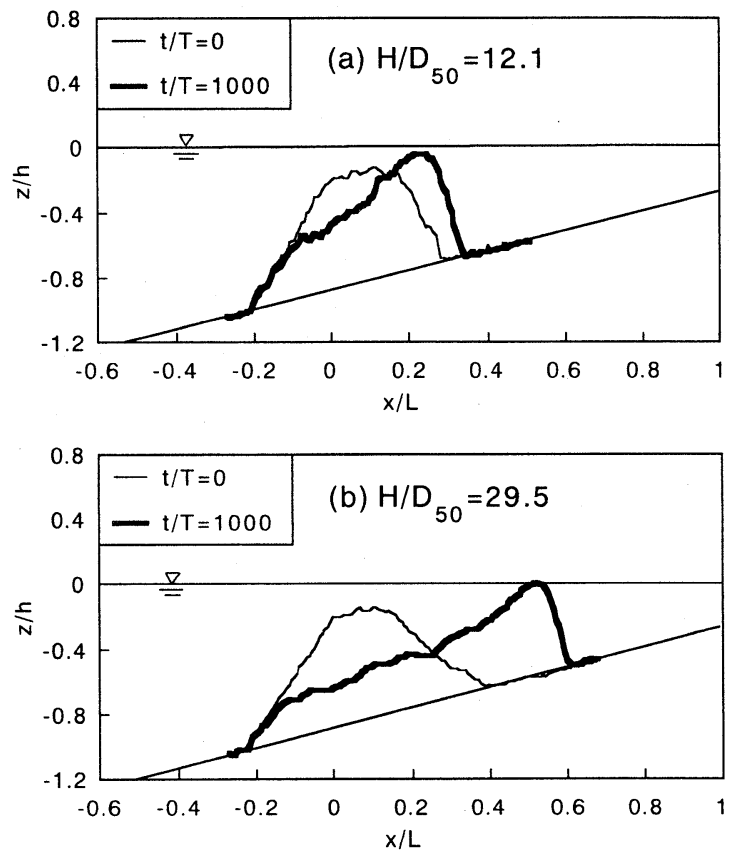

図-15 断面 2 次元実験による変形 $(B / L=0.168)$

\section{（2）被害レベルSに関する比較}

被害レベル $S\left(S=A e / D_{50}{ }^{2}, A e\right.$ : 侵食面積) は，堤体 岸沖方向の一つの断面に着目して算出した。図-16 に，被害レベル $S$ に関する平面実験の結果と断面 2 次元実験の結果の比較を示す. 断面 2 次元実験の結 果は，著者ら ${ }^{7)}$ の結果からカーブフィットした実線 で示している. 平面実験と断面 2 次元実験の相違を 純粋に比較するためには, 直角入射波による堤体中 央部 (主幹部) の変形を取り扱う必要があるが，斜 め入射波により堤体端部に大きな被災が生じる可能 性があるため，ここでは堤体端部の比較も行った。

図-16 (a) に示す沿い流れ上手側端部 $(y / L r=0.133)$ 
での比較では, 断面 2 次元実験の平均值とは大きく 異なり，激しく侵食されていることが分かる．図一 16 (b) に示す堤体中央部 $(y / L r=0.533)$ では, 被害レべ ルの值は断面 2 次元の実験結果の平均值より依然と して大きいが，沿い流れ上手側端部ほどの差は見ら れない。したがって，今回の実験条件内においても， 堤体中央部では堤体端部の影響が小さくなっている と言える。図-16(c)に示す沿い流れ下手側端部 $(y / L=0.933)$ では, 平面実験の結果がややぼらついて おり，沿い流れ下手側の端部の影響が現れていると 考えられる. 以上のことから，端部の影響があまり 見られない堤体中央部に関しては，断面 2 次元実験 の結果を用いて捨石の安定性および堤体の変形の議 論は可能であるが，堤体端部，特に斜め入射時の沿 い流れ上手側端部に関しては, 断面 2 次元実験の結 果では捨石の安定性や堤体の変形の議論を行うこと は難しい場合もあると考えられる。
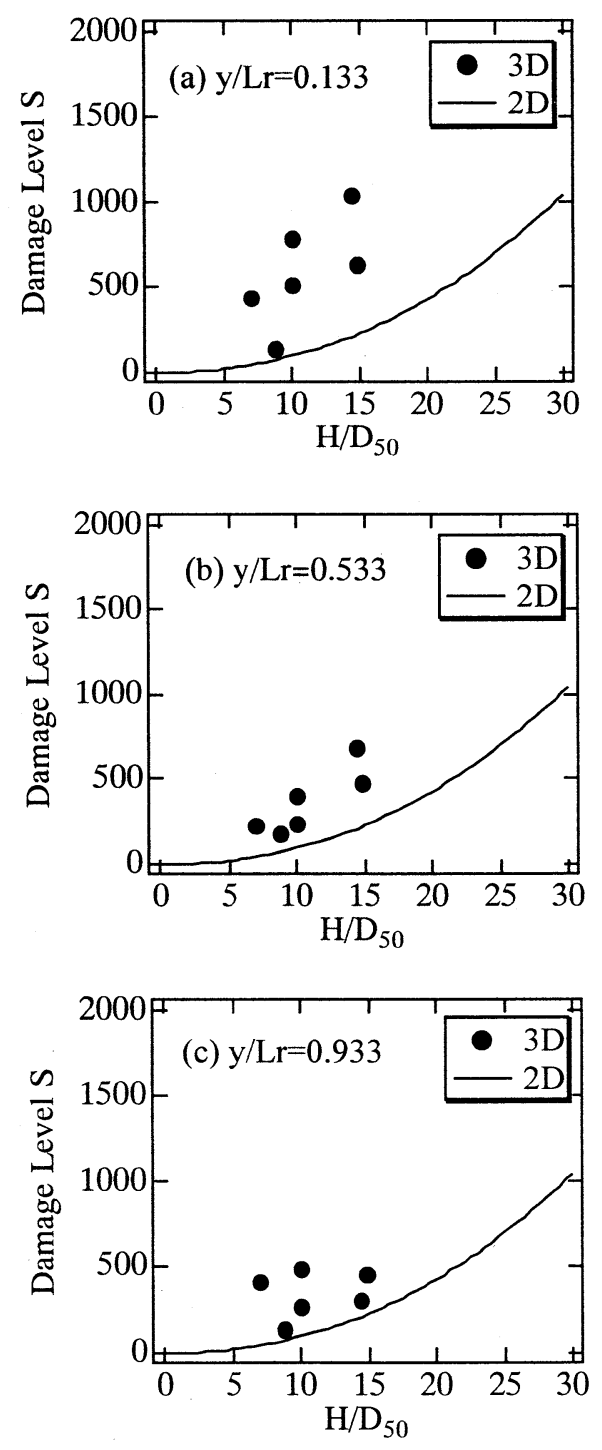

図-16 被害レベルSの比較

\section{5. 結語}

本研究では，設計值を超える外力が作用する場合 における捨石潜堤の変形を平面実験により検討した。 得られた主要な結果を以下にまとめる.

(1) 潜堤の堤体端部は変形しやすく, 沿い流れ上手 側端部では沖側からの砕波と側面からの砕波に より捨石が移動しやすく，沿い流れ下手側端部 では初期移動を始めた捨石が沿い流れにより側 方に流出しやすいためと考えられる。

(2) 沿い流れ上手側の侵食域にあった捨石は沿い流 れ下手側に移動するが，その大部分は上手側端 部から 1 波長以内に堆積する。したがって, 堤 体長 $L r$ と入射波長 $L$ の比 $L r / L$ が 1 以下の場合は堤 体長全域にわたって背後に捨石が堆積し,$L r / L$ が 1 以上の場合は堤体中央部に捨石が堆積する ことになる.

(3) 平面実験では断面 2 次元実験よりはるかに大き な侵食が堤体に生じ，捨石の岸向き移動距離も 大きくなった。平面実験での岸沖断面ごとに被 害レベルSを算定したが，特に端部において断面 2 次元実験の結果とは大きく異なった。した がって, 断面 2 次元実験では安定性の議論がで きない場合もあると言える。

謝辞：本研究を行うにあたり，前田記念工学振興財 団の助成を受けた。ここに記して謝意を表します。

\section{参考文献}

1) 鹿島遼一, 今泉正次, 戸田泰和：被災事例から見た防 波堤 - 防波護岸の波浪被災特性, 第33回海岸工学講演 会論文集, pp.626-630, 1986.

2) 五明美智男, 堺 和彦, 高山知司, 寺内 潔, 高橋重 雄 : 消波ブロック被覆堤のブロックの安定性に関する 現状調查, 海岸工学論文集, 第42巻, pp. 901-905, 1995.

3) Burcarth, H. F. and Frigaard P. : on 3-Dimensional Stability of Reshaping Breakwater, Proc. of the $21^{s t}$ Int'l Conference on Coastal Engineering, ASCE, pp. 2284-2298, 1988.

4) 松見吉晴, 大野賢一：多方向不規則波に対する堤頭部 上の流速特性と被災パターン，海岸工学論文集，第42 巻, pp. 881-885, 1995.

5) 木村克俊, 上久保勝美, 坂本洋一, 水野雄三, 竹田英 章, 林 倫史: 消波ブロック被覆堤の堤頭部における ブロックの耐波安定性, 海岸工学論文集, 第44巻, pp. 956-960, 1997.

6) 社団法人 日本港湾協会：港湾の施設の技術上の基 準・同解説, pp. 132-135, 1989.

7) Araki, S., Fujiwara, Y., Miyazaki, T. and Deguchi, I. : Experimental Study on the Influence of the Crest Width on the Deformation of Submerged Breakwater, Proc. of the $1 l^{\text {th }}$ Int'l Offshore and Polar Engineering Conference, ISOPE, Vol. III, pp. 624-630, 2001. 